\title{
Disappearing pulse: proximal humerus fracture with acute thrombosis of axillary artery
}

\author{
Nikhil Hegde (D), Raghuraj Suresh Kundangar, Ampar Nishanth, \\ Shyamasunder N Bhat
}

Manipal Academy of Higher Education, Manipal, Karnataka, India

\section{Correspondence to} Dr Raghuraj Suresh Kundangar; raghurajsk74@gmail.com

Accepted 22 March 2021

\section{DESCRIPTION}

A 48-year-old rickshaw driver presented to the emergency department following a road traffic accident in which he sustained a closed injury to the left shoulder and neck. On clinical examination, his Glasgow Coma Scale was 15/15; higher mental functions and cranial nerve examinations were remarkably normal. He had severe tenderness over the shoulder with restricted range of movement. Distal neurovascular examination revealed pointing index sign present and numbness in the hand with normal radial pulse on initial examination. Radiographs showed Neer's four part fracture of left proximal humerus, with gross medial displacement of the distal fragment (figure 1A). The patient also had a type II dens fracture.

In view of the gross medial displacement of fracture fragments and median nerve injury, the patient was reassessed at the end of each hour. At 4 hours following initial evaluation it was seen that the limb appeared cold with absent radial pulse. CT angiography relieved an absent flow in the distal part of the axillary artery close to a bony spike of the distal fracture fragment (figure 2B). The patient was then taken up for emergency open reduction and internal fixation. The fracture was exposed using a deltopectoral approach and the axillary artery was explored. The artery was found to be intact, however there was a thrombus noted (figure 2A). Thrombectomy was performed and the vascularity was restored. Median nerve was found intact and contused. The odontoid fracture was treated conservatively with a spinal brace. The patient

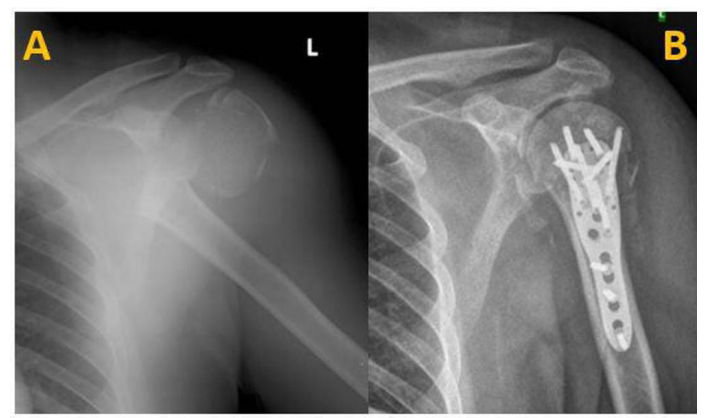

Figure 1 (A) Radiograph showing Neer's four-part fracture of the left proximal humerus, with gross medial displacement of the distal fragment. (B) Postoperative radiographs following ORIF showing reduced fracture with implant in situ.

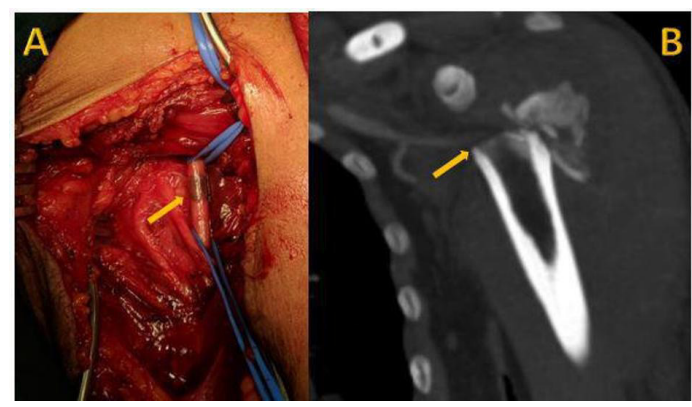

Figure 2 (A) Intraoperative clinical photo showing thrombosed section of axillary artery. (B) CT scan showing absent flow in the distal part of the axillary artery close to a bony spike of the distal fracture fragment.

did not develop any signs of reperfusion injury. The probable reason for this is early fracture fixation and vascular exploration, which was done within 3 hours of acute thrombosis. Postoperatively early mobilisation of the shoulder was started and he achieved good range of movement at 6-weeks follow-up with complete neurological recovery of median nerve.

Proximal humerus fractures are common orthopaedic injuries constituting about $5 \%$ of all fractures. ${ }^{1}$ However, vascular injuries with proximal humerus fractures are relatively uncommonly seen even though, anatomically they are in close relation with each other. However, injury to the artery by a sharp bony fragment can cause rupture and intimal tear leading to thrombosis, with a higher risk in a calcified artery. After a thorough review of the literature, we have identified 14 additional cases $(7$ surgical neck fractures with shaft medialisation, 5 fracture dislocations and 2 undisplaced fractures)..$^{2-8}$

It must be noted that on initial presentation peripheral pulses may be palpable, especially in

\section{Patient's perspective}

I had visited the orthopaedic surgeon who diagnosed me to have a fracture of the left proximal humerus, and a type II dens fracture. However, during my course of stay in the hospital, I was noted to have a vascular injury, for which I underwent emergency surgery. Now I am better. I understand that this manuscript will make the readers aware of this rare clinical presentation and thereby provide better patient care. 


\section{Learning points}

- Proximal humerus fractures with gross medial displacement of distal fragment must be evaluated for vascular injuries.

- Presence of distal arterial pulse at the time of primary evaluation does not rule out vascular injury.

- Repeated clinical examination and early surgical intervention give good outcomes.

cases with intimal tears, pulses diminish only after thrombosis of the artery. Therefore, palpable pulses are no guarantee that axillary artery injury has not occurred. ${ }^{9}$ In our case distal pulses were initially present and only on repeat examination vascular involvement and thrombosis of the artery were picked up. Careful repeated examination should be emphasised, especially when there is gross medial displacement of the fractured fragments.

\section{Twitter Shyamasunder N Bhat @shyambhatn}

Contributors NH was involved in designing, conducting and reporting of the case, and writing the original draft of the manuscript. RSK was involved in conceptualisation, planning, writing the review and editing the manuscript. AN contributed to acquisition of data and project administration. SNB did review, editing and interpretation of the case.

Funding The authors have not declared a specific grant for this research from any funding agency in the public, commercial or not-for-profit sectors.
Competing interests None declared.

Patient consent for publication Obtained.

Provenance and peer review Not commissioned; externally peer reviewed.

\section{ORCID iDs}

Nikhil Hegde http://orcid.org/0000-0003-4359-0090

Shyamasunder N Bhat http://orcid.org/0000-0001-9545-4838

\section{REFERENCES}

1 Menendez ME, Ring D, Heng M. Proximal humerus fracture with injury to the axillary artery: a population-based study. Injury 2015;46:1367-71.

2 Thorsness R, English C, Gross J, et al. Proximal humerus fractures with associated axillary artery injury. J Orthop Trauma 2014;28:659-63.

3 Yagubyan M, Panneton JM. Axillary artery injury from humeral neck fracture: a rare but disabling traumatic event. Vasc Endovascular Surg 2004;38:175-84.

4 Baxter MP, Wiley JJ. Fractures of the proximal humeral epiphysis. their influence on humeral growth. J Bone Joint Surg Br 1986;68-B:570-3.

5 Papaconstantinou HT, Fry DM, Giglia J, et al. Endovascular repair of a blunt traumatic axillary artery injury presenting with limb-threatening ischemia. J Trauma 2004:57:180-3.

6 Wera GD, Friess DM, Getty PO, et al. Fracture of the proximal humerus with injury to the axillary artery in a Boy aged 13 years. J Bone Joint Surg Br 2006;88-B:1521-3.

7 Gallucci G, Ranalletta M, Gallucci J, et al. Late onset of axillary artery thrombosis after a nondisplaced humeral neck fracture: a case report. J Shoulder Elbow Surg 2007;16:e7-8.

8 Suttie SA, Mofidi R, Howd A, et al. Use of a Javidtrade mark shunt in the management of axillary artery injury as a complication of fracture of the surgical neck of the humerus: a case report. J Med Case Rep 2008;2:259.

9 Peters RM, Menendez ME, Mellema JJ, et al. Axillary artery injury associated with proximal humerus fracture: a report of 6 cases. Arch Bone Jt Surg 2017;5:52-7.

Copyright 2021 BMJ Publishing Group. All rights reserved. For permission to reuse any of this content visit

https://www.bmj.com/company/products-services/rights-and-licensing/permissions/

BMJ Case Report Fellows may re-use this article for personal use and teaching without any further permission.

Become a Fellow of BMJ Case Reports today and you can:

- Submit as many cases as you like

- Enjoy fast sympathetic peer review and rapid publication of accepted articles

- Access all the published articles

Re-use any of the published material for personal use and teaching without further permission

\section{Customer Service}

If you have any further queries about your subscription, please contact our customer services team on +44 (0) 2071111105 or via email at support@bmj.com.

Visit casereports.bmj.com for more articles like this and to become a Fellow 